S. I. Trubachev ${ }^{21}$, PhD, Associate professor,

DOI: http://dx.doi.org/10.20535/0203-3771352018143041

O. M. Alekseychuk ${ }^{22}, P h D$, Associate professor

\title{
THE STRESS-STRAIN STATE DETERMINATION OF A CEN- TRIFUGAL TURBOMACHINE WHEEL
}

Ua Метою роботи є аналітичне визначення напружено-деформованого стану колеса центробіжної турбомашини. Розрахунки на міцність елементів енергетичного обладнання були розглянуті у роботах [1-3]. Розрахунку робочого колеса як конструктивно ортотропного диска присвячено роботи $[4$, 5]. Задачу розрахунку НДС робочого колеса можна звести до рішення диференціального рівняння, яке виражає умови рівноваги елемента робочого колеса. У роботі представлено аналітичне визначення напружено деформованого стану колеса центробіжної турбомашини. Було розглянуто дві моделі. Під час розрахунку у першій моделі колесо вважалось ортотропним диском, в іншій - не враховувалась жорсткість лопаток, які розглядались як приєднана маса. Отримані формули можуть бути корисними для проектувальників у галузі енергетичного машинобудування.

Цель работы аналитическое определение напряженно- 
деформированного состояния колеса центробежной турбомашины. Расчеты на прочность элементов энергетического оборудования были рассмотрены в работах [1-3]. Расчетам рабочего колеса как конструктивно ортотропного диска посвящены работы $[4,5]$. Задачу расчета НДС рабочего колеса можно свести к решению дифференциального уравнения, которое выражает условия равновесия элемента рабочего колеса. В работе представлено аналитическое определение напряженно деформированного состояния колеса центробежной турбомашины. Были рассмотрены две модели. При расчете в первой модели колесо считалось ортотропными диском, в другой -не учитывалась жесткость лопаток, которые рассматривались как присоединенная масса. Полученные формулы могут быть полезными для проектировщиков в области энергетического машиностроения.

\section{Foreword}

The purpose of the work is to determine the stress-strain state of the centrifugal turbomachine wheel, in which, when we made calculating in one case, the wheel was considered as constructively orthotropic disk, in the other case we didn't took into account the stiffness of the blades, which were considered as the joining mass. Calculations of elements of power equipment were also examined in works [1-3].

The calculation of working wheel as a constructively orthotropic disk was investigated in the works $[4,5]$. The problem is reduced to the solution of the boundary integral equation in relation to the intensity of radial effort in these works.

\section{Formulation and solution of the problem}

The calculation of working wheel can be reduced to a solution of the differential equation, which expresses the equilibrium conditions of the wheel element (1).

$$
\frac{d N_{r}}{d r}-\frac{1}{r}\left(N_{\theta}-N_{r}\right)+\omega^{2} r p^{*} h_{d}=0,
$$

where $N_{r}$ is the intensity of radial efforts;

$N_{\theta}$ is the intensity of circular efforts;

$$
p^{*}=p\left[1+\frac{z F(r)}{\pi r h_{d}}\right],
$$

where $p$ is the disk material and blade material density. formula:

Blade section area of the cylindrical surface of the radius $r$ we find by the

$$
F(r)=\frac{h_{l} \delta_{l}}{\cos \varphi}
$$


where $\delta_{l}$-is the middle blade toning.

$N_{r}$ and $N_{\theta}$ expression for a constructively orthotropic disk have the form

$$
\begin{aligned}
& N_{r}=\frac{E h_{d}}{1-\mu^{2}}\left(\frac{d u}{d r}+\mu \frac{u}{r}\right)+E_{l}\left(\frac{d u}{d r} \cos ^{2} \varphi+\frac{u}{r} \sin ^{2} \varphi\right) \frac{z F(r)}{\pi r} \cos ^{2} \varphi ; \\
& N_{\theta}=\frac{E h_{\partial}}{1-\mu^{2}}\left(\frac{u}{r}+\mu \frac{d u}{d r}\right)+E_{l}\left(\frac{d u}{d r} \cos ^{2} \varphi+\frac{u}{r} \sin ^{2} \varphi\right) \frac{z F(r)}{\pi r} \sin ^{2} \varphi,
\end{aligned}
$$

where $u$ is the radial displacement; $\varepsilon_{r}$ and $\varepsilon_{\theta}$ are the disk element deformation (5).

$$
\varepsilon_{r}=\frac{d u}{d r} ; \varepsilon_{\theta}=\frac{u}{r}
$$

The reduced elastic modulus of the blade material is

$$
E_{l}=\frac{E}{1+\frac{2(1+\mu) z F(r)}{\pi r h_{\mathbb{I}}} \sin ^{2} \varphi \cos ^{2} \varphi}
$$

Substituting expressions (4) into equation (1) and denoting

$$
\begin{gathered}
a_{1}=\frac{2(1+\mu) z F(r)}{\pi h_{d}} \sin ^{2} \varphi \cos ^{2} \varphi ; \\
a_{2}=\left(1-\mu^{2}\right) a_{3} ; a_{3}=\frac{z F(r)}{\pi h_{d}} ; \\
k=-\frac{\left(1-\mu^{2}\right) \omega^{2} p}{E}
\end{gathered}
$$

let us give the equation (1) to the form

$$
\frac{d^{2} u}{d r^{2}}+p(r) \frac{d u}{d r}+q(r) u=f(r) .
$$

Where are

$$
\begin{gathered}
p(r)=\frac{1}{r} \frac{1+\frac{a_{2}}{a_{1}+r} \cos ^{4} \varphi\left(1-\frac{r}{a_{1}+r}\right)}{1+\frac{a_{2}}{a_{1}+r} \cos ^{4} \varphi} ; \\
q(r)=-\frac{1}{r^{2}} \frac{\frac{a_{2}}{a_{1}+r} \sin ^{2} \varphi\left(\frac{r \cos ^{2} \varphi}{a_{1}+r}+\sin ^{2} \varphi\right)+1}{1+\frac{a_{2}}{a_{1}+r} \cos ^{4} \varphi} ;
\end{gathered}
$$




$$
f(r)=k \frac{r+a_{3}}{1+\frac{a_{2}}{a_{1}+r} \cos ^{4} \varphi}
$$

The boundary conditions can be written in the form

$$
\begin{aligned}
& \alpha_{0} u_{2}\left(R_{1}\right)+\alpha_{1} u_{2}\left(R_{1}\right)=A ; \\
& \beta_{0} u_{2}\left(R_{2}\right)+\beta_{1} u_{2}\left(R_{2}\right)=B .
\end{aligned}
$$

Conditions (9) we're obtained by examining the free parts of the hub $\left(r=R_{0}\right)$ and disk $\left(r=R_{2}\right)$, and coupling the drive with hub $\left(r=R_{1}\right)$ :

$$
\begin{aligned}
& \text { 1. } r=R_{0}, \quad N_{r 1}=0 ; \\
& \text { 2. } r=R_{1}, \quad u_{1}=u_{2} ; \\
& \text { 3. } r=R_{1}, \quad N_{r 1}=N_{r 2} ; \\
& \text { 4. } r=R_{2}, \quad N_{r 2}=0 .
\end{aligned}
$$

Here are the indexes 1 and 2 at $N_{r}$ and $u$ are refer to the hub and disk respectively. Intensity of radial forces in the hub is

$$
N_{r 1}=\sigma_{r} h_{c}=\frac{E h_{c}}{1-\mu^{2}}\left(\frac{d u_{1}}{d r}+\mu \frac{u_{1}}{r}\right) .
$$

Radial displacement of hub points is

$$
u_{1}=C_{1} r+\frac{C_{2}}{r}-\frac{1-\mu^{2}}{8 E} p \omega^{2} r^{3} .
$$

Substituting expression (12) into formula (11) and taking into account the first condition (10), we're obtain

$$
(1+\mu) C_{1}-(1-\mu) \frac{1}{R_{0}^{2}} C_{2}=\frac{1-\mu^{2}}{8 E} p R_{0}^{2}(3+\mu) \omega^{2}
$$

From the second condition (10) we will have

$$
R_{1} C_{1}+\frac{1}{R_{1}} C_{2}=u_{2}\left(R_{1}\right)+\frac{1-\mu^{2}}{8 E} p \omega^{2} R_{1}^{3} .
$$

After substituting the expression (12) into formula (11) and taking into account the third condition (10), as well as equation (4), we're obtain

$$
\begin{aligned}
\frac{h_{c}}{(1-\mu)} C_{1} & -\frac{h_{c}}{(1+\mu) R_{1}^{2}} C_{2}-\frac{(3+\mu)}{8 E} p h_{c} \omega^{2} R_{1}^{2}= \\
& =\frac{h_{\text {д }}}{\left(1-\mu^{2}\right)}\left[u_{2}^{\prime}\left(R_{1}\right)+\mu \frac{u_{2}\left(R_{1}\right)}{R_{1}}\right]+ \\
& +\frac{z F(r)}{A\left(R_{1}\right) \pi R_{1}} \cos ^{2} \varphi \cdot\left[u_{2}^{\prime}\left(R_{1}\right) \cos ^{2} \varphi+\frac{u_{2}\left(R_{1}\right)}{R_{1}} \sin ^{2} \varphi\right] .
\end{aligned}
$$


Using the last condition (10), we will have

$$
\begin{gathered}
\frac{h_{d}}{\left(1-\mu^{2}\right)}\left[u_{2}^{\prime}\left(R_{2}\right)+\mu \frac{u_{2}\left(R_{2}\right)}{R_{2}}\right]+\frac{z F(r)}{A\left(R_{2}\right) \pi R_{2}} \cos ^{2} \varphi \times \\
\times\left[u_{2}^{\prime}\left(R_{2}\right) \cos ^{2} \varphi+\frac{u_{2}\left(R_{2}\right)}{R_{2}} \sin ^{2} \varphi\right]=0
\end{gathered}
$$

Where

$$
A(r)=\frac{E}{E_{l}(r)} .
$$

Solving the equation (13) and (14) with respect to $C_{1}$ and $C_{2}$, we're obtain

$$
\left\{\begin{array}{l}
C_{1}=-k b_{1}+b_{2} u_{2}\left(R_{1}\right) ; \\
C_{2}=-k b_{3}+b_{4} u_{2}\left(R_{1}\right) .
\end{array}\right.
$$

Where are

$$
\begin{aligned}
& b_{1}=\frac{1}{8} \frac{R_{1}^{2}}{R_{2}^{2}} \frac{(3+\mu) \frac{R_{0}^{4}}{R_{4}^{1}}+(1-\mu)}{(1+\mu) \frac{R_{0}^{2}}{R_{1}^{2}}+(1-\mu)} \\
& b_{2}=\frac{(1-\mu)}{R_{1}\left[(1+\mu) \frac{R_{0}^{2}}{R_{1}^{2}}+(1-\mu)\right]} \text {; } \\
& b_{3}=\frac{1}{8} \frac{R_{1}^{4}}{R_{2}} \frac{(1+\mu) \frac{R_{0}^{2}}{R_{1}^{2}}-(3+\mu) \frac{R_{0}^{4}}{R_{1}^{4}}}{(1+\mu) \frac{R_{0}^{2}}{R_{1}^{2}}+(1-\mu)} ; \\
& b_{4}=\frac{(1+\mu)}{\frac{R_{1}}{R_{0}}\left[(1+\mu) \frac{R_{0}^{2}}{R_{1}^{2}}+(1-\mu)\right]} .
\end{aligned}
$$

we're obtain the values of coefficients for boundary conditions with two points (9) after substituting expression (17) into equations (15) and (16) with farther transformations:

$$
\begin{aligned}
& \alpha_{0}=\frac{h_{c}}{1-\mu} b_{2}-\frac{h_{c}}{(1+\mu) R_{1}^{2}} b_{4}-\frac{h_{d}}{\left(1+\mu^{2}\right) R_{1}}-\frac{z F(r)}{A\left(R_{1}\right) \pi R_{1}^{2}} \sin ^{2} \varphi \cos ^{2} \varphi ; \\
& \alpha_{1}=-\frac{h_{d}}{\left(1+\mu^{2}\right)}-\frac{z F(r)}{A\left(R_{1}\right) \pi R_{1}} \cos ^{4} \varphi ;
\end{aligned}
$$




$$
\begin{aligned}
& A=\frac{h_{c}}{(1+\mu) R_{1}^{2}} b_{3}+\frac{h_{c}}{1-\mu} b_{1}+\frac{3+\mu}{8 E} p h_{c} \omega^{2} R_{1}^{2} ; \\
& \beta_{0}=\frac{h_{\partial} \mu}{\left(1+\mu^{2}\right) R_{2}}+\frac{z F(r)}{A\left(R_{2}\right) \pi R_{2}^{2}} \sin ^{2} \varphi \cos ^{2} \varphi ; \\
& \beta_{1}=\frac{h_{\partial}}{1+\mu^{2}}+\frac{z F(r)}{A\left(R_{2}\right) \pi R_{2}} \cos ^{4} \varphi ; B=0 .
\end{aligned}
$$

The tension in the disk is determined by the formulas:

$$
\left\{\begin{array}{l}
\sigma_{r}=\frac{E}{1-\mu^{2}}\left(\frac{d u}{d r}+\mu \frac{u}{r}\right) \\
\sigma_{\theta}=\frac{E}{1-\mu^{2}}\left(\frac{u}{r}+\mu \frac{d u}{d r}\right)
\end{array}\right.
$$

and tensile stresses in the blade along its axis

$$
\sigma_{l}=E_{l}\left(\frac{d u}{d r} \cos ^{2} \varphi+\frac{u}{r} \sin ^{2} \varphi\right) .
$$

Let's consider the calculation of the working wheel without taking into account the stiffness of the blades, which were considered as the joining mass. In this case, the differential equation (7) takes the form

$$
\frac{d^{2} u}{d r^{2}}+\frac{1}{r} \frac{d u}{d r}-\frac{u}{r^{2}}=k\left(r+a_{3}\right),
$$

where the term $a_{3}$ takes into account the blades joining mass.

The solution of equation (22) is possible in a closed form. To do this, let's transform the left-hand side of the equation into a form

$$
\frac{d}{d r}\left[\frac{1}{r} \frac{d(u r)}{d r}\right]=k\left(r+a_{3}\right) .
$$

We integrate the equation (23):

$$
u=k\left(\frac{1}{8} r^{3}+\frac{a_{3}}{3} r^{2}\right)+C_{1} r .
$$

Derivative radial movement is

$$
u^{\prime}=k\left(\frac{3}{8} r^{2}+\frac{2}{3} a_{3} r\right)+C_{1} .
$$

Constant $C_{1}$ we find from the condition on the outer edge of the disk

$$
r=R_{2} ; N_{r}=0 \text {. }
$$

Expression for $N_{r}$ in this case has the form 


$$
N_{r}=\sigma_{r} h_{d}=\frac{E h_{d}}{1-\mu^{2}}\left(\frac{d u}{d r}+\mu \frac{u}{r}\right) .
$$

After substitution the expression (27) in condition (26), we obtain

$$
C_{1}=-k \frac{\frac{1}{8} R_{2}^{2}(3+\mu)+\frac{1}{3} a_{3} R_{2}(2+\mu)}{1+\mu} .
$$

After substitution the expression for $C_{1}$ in expressions (24) and (25), we calculate the value $u$ and $u^{\prime}$ in calculated cross-sections. We determine in the formulas (20) the stresses in the disk by values $u$ and $u^{\prime}$.

\section{Conclusions}

The paper presents an analytical definition of a circular turbomachine wheel center stress strain state. Two models were investigated. The wheel was considered as orthotropic disc in the first model calculations, in the other one was not taken into account the stiffness of the blades, which were considered as joining mass. The resulting formulas may be useful for designers in the field of power engineering.

\section{References}

1. Яхно Б. О. Напряжено-деформированное состояние цилиндрических толстостенных перфорированных оболочек / Б. О.Яхно, С. И. Трубачев. // Вісник Національного технічного університету України «Київський політехнічний інститут» серія Машинобудування. 2015. - C. 126-130.

2. Trubachev $S$. Vibrations of aircraft engines turbine blades with hysteretic energy dissipation / S. Trubachev, O. Alekseychuk. // Mechanics of gyroscopic systems. -2016 . - p. 126-132.

3. Baranyuk $A$. Strength investigation of a propeller tube with an evenly developed surface, taking into account the internal flow stream / A. Baranyuk, S. Trubachev, S. Reva. // Scientific Journal «ScienceRise».-2017. - №2.p. 23-27.

4. Григоренко Я. М. Методы расчета оболочек / Я. М. Григоренко, А. Т. Василенко. - Киев: Наук. Думка, 1981. - 544 с.

5. Литвинов В.Г. Оптимизация в эллиптических граничных задачах с приложенными к механике / В. Г. Литвинов. - М.: Наука, 1987. - 366 с. 